\title{
Magnetic minerals and magnetic properties of the Siwalik Group sediments of the Karnali river section in Nepal
}

\author{
Pitambar Gautam ${ }^{1,2}$, Azumi Hosoi ${ }^{1}$, Kamal Raj Regmi ${ }^{1,2}$, Dharma Raj Khadka ${ }^{2}$, and Yoshiki Fujiwara ${ }^{1}$ \\ ${ }^{1}$ Division of Earth and Planetary Sciences, Graduate School of Science, Hokkaido University, N10 W8, Sapporo 060-0810, Japan \\ ${ }^{2}$ Central Department of Geology, Tribhuvan University, Kirtipur, Kathmandu, Nepal
}

(Received July 5, 1999; Revised April 10, 2000; Accepted April 10, 2000)

\begin{abstract}
Sandstones and siltstones collected from the Siwalik molasse sequence ( $\sim 16$ to $5 \mathrm{Ma})$ of the Karnali river section have been studied for their magnetic properties. Behavior of the specimens during demagnetization (of the NRM and IRM) and magnetic susceptibility vs. temperature data suggest that goethite, maghemite/magnetite, and hematite are the main magnetic minerals in the section. Goethite, carrying a recent component, is the dominant magnetic mineral in the fine-grained lithologies from the lower part. Maghemite and magnetite, which also carry a secondary remanence, occur in the sandstones from the upper part. Hematite, mainly of detrital origin, is present in the whole sequence. The magnetic fabric is defined by mainly oblate AMS ellipsoids and a low degree of anisotropy $\left(P^{\prime}<1.20\right)$. The magnetic lineations (declinations: $75^{\circ}-130^{\circ}$ or $245^{\circ}-310^{\circ}$; peak orientation: $\left.290^{\circ} / 2.8^{\circ}\right)$ are subparallel to the fold axes/bedding strikes/thrust fronts (WNW-ESE). The initial sedimentary-compactional fabric has been overprinted by a secondary tectonic fabric, which was probably induced by mild deformation active in the compressive tectonic setting.
\end{abstract}

\section{Introduction}

During the last two decades, it has been demonstrated that the chronology of the Mio-Pliocene fluvial sediments of the Siwalik Group from Pakistan, India and Nepal can be deciphered through correlation of magnetic polarity reversal patterns to the geomagnetic polarity time scale (GPTS) (Barndt et al., 1978; Opdyke et al., 1979; Tauxe and Opdyke, 1982; Johnson et al., 1982, 1983; Tokuoka et al., 1986; Ranga Rao et al., 1988; Opdyke, 1990; Appel et al., 1991; Harrison et al., 1993; Gautam and Appel, 1994; Burbank et al., 1996; Rösler et al., 1997). These data are invaluable for regional chronological correlation throughout the Sub-Himalayan belt. In addition, studies on rock magnetic properties and magnetic fabrics have also been useful for our knowledge of magnetic carriers of remanences and tectonic deformation of the region (Tauxe et al., 1990; Gautam and Pant, 1996; Rösler and Appel, 1998; Gautam and Rösler, 1999). In spite of this research effort, the eastern and western sectors in Nepal remain sparsely studied and little is known about their chronology and tectonic development.

In this paper, we present rock magnetic properties of sediments along the Karnali river (KR) in western Nepal (Fig. 1(a)). A recent magnetostratigraphic study (Gautam and Fujiwara, 1999) suggests that the sediments comprising a $3560 \mathrm{~m}$ thick sequence were deposited during a time span of over 11 Myrs ( $\sim 16$ to $5 \mathrm{Ma})$. Hence, the KR section has the oldest Siwalik sediments in Nepal. A dense sampling $(8 \mathrm{~m}$ in average) allows resolution of the subtle variations in magnetic properties. We also present data related to the magnetic

Copy right (C) The Society of Geomagnetism and Earth, Planetary and Space Sciences (SGEPSS); The Seismological Society of Japan; The Volcanological Society of Japan; The Geodetic Society of Japan; The Japanese Society for Planetary Sciences. fabric, which provides clues to the tectonic development of the region.

\section{Geological Outline and Sampling Scheme}

The foreland basin sediments constituting the KR gorge are represented by clastic sediments that prograded into the Himalayan foredeep (Fig. 1(b)). Lithologically, they are divisible into the Lower Siwaliks (LS), Middle Siwaliks (MS) and Upper Siwaliks (US). The region represents a piggy-back imbricate thrust package lying between the Main Frontal Thrust (MFT) in the south and the Main Boundary Thrust (MBT) in the north (Mugnier et al., 1998). The foreland basin package may be viewed as a composite of two large-scale thrust belts separated by an extensive intra-Siwalik thrust known as the Main Dun Thrust (MDT). The southern belt, $\sim 12 \mathrm{~km}$ wide, comprises all the Siwalik lithologies (LS, MS, US: $>4 \mathrm{~km}$ thick in total) which form a continuous sequence with a coarsening upward trend. The northern belt, $\sim 6 \mathrm{~km}$ wide, is a complex collage of splays bounded by subordinate thrusts, which merge with the major thrusts at depth.

Sampling was carried out along a $5.6 \mathrm{~km}$ long route across the LS and MS lithologies of the southern belt (Fig. 1(c)). The route starts at the first exposure $\left(28^{\circ} 39.02^{\prime} \mathrm{N} ; 8^{\circ} 17.20^{\prime} \mathrm{E}\right)$ of sandstone on the road at the northern end of the Chisapani Bazaar and ends at the left bank of the Karnali river near its confluence with a tributary flowing from NE. The lowermost part of the LS, lying immediately to the north of the MFT and representing a few hundred meters in thickness, could not be sampled due to lack of continuous exposures. Likewise, the uppermost part of the MS sequence $(<100 \mathrm{~m})$ and the US sequence $(\sim 300 \mathrm{~m})$ were not sampled due to accessibility problems. The total sampling thickness is $3560 \mathrm{~m}$ (Fig. 2). 
(a)

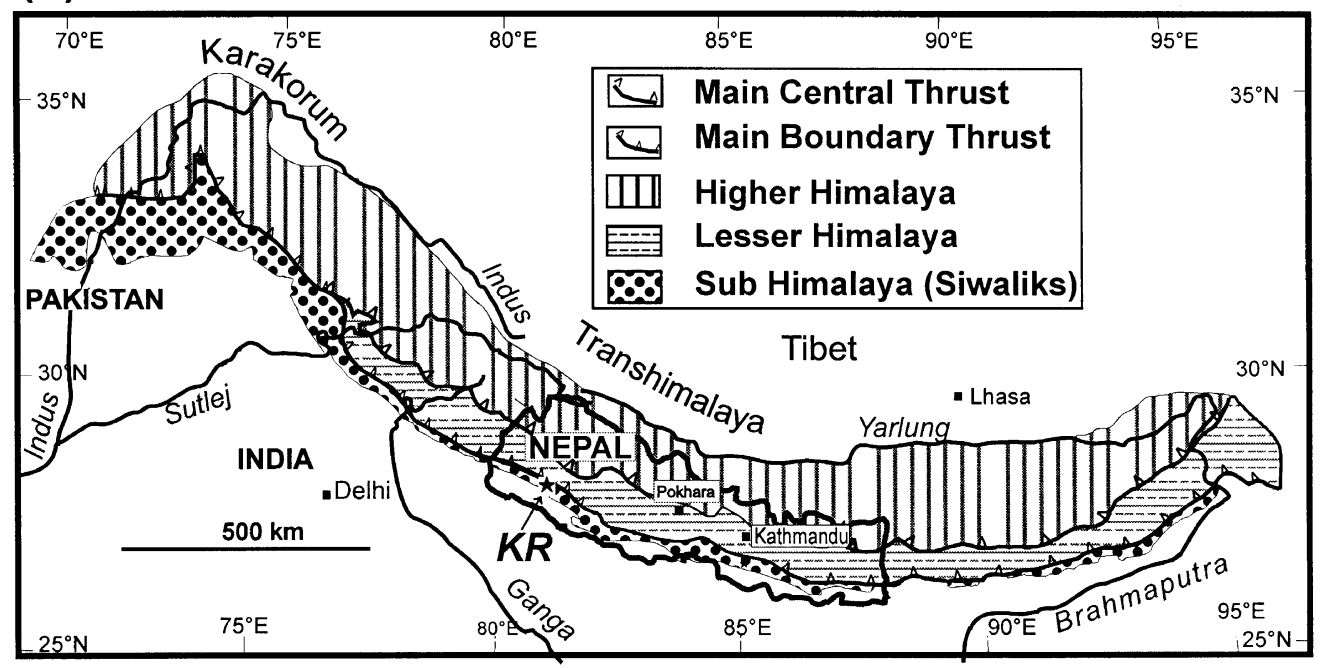

(b)

(c)

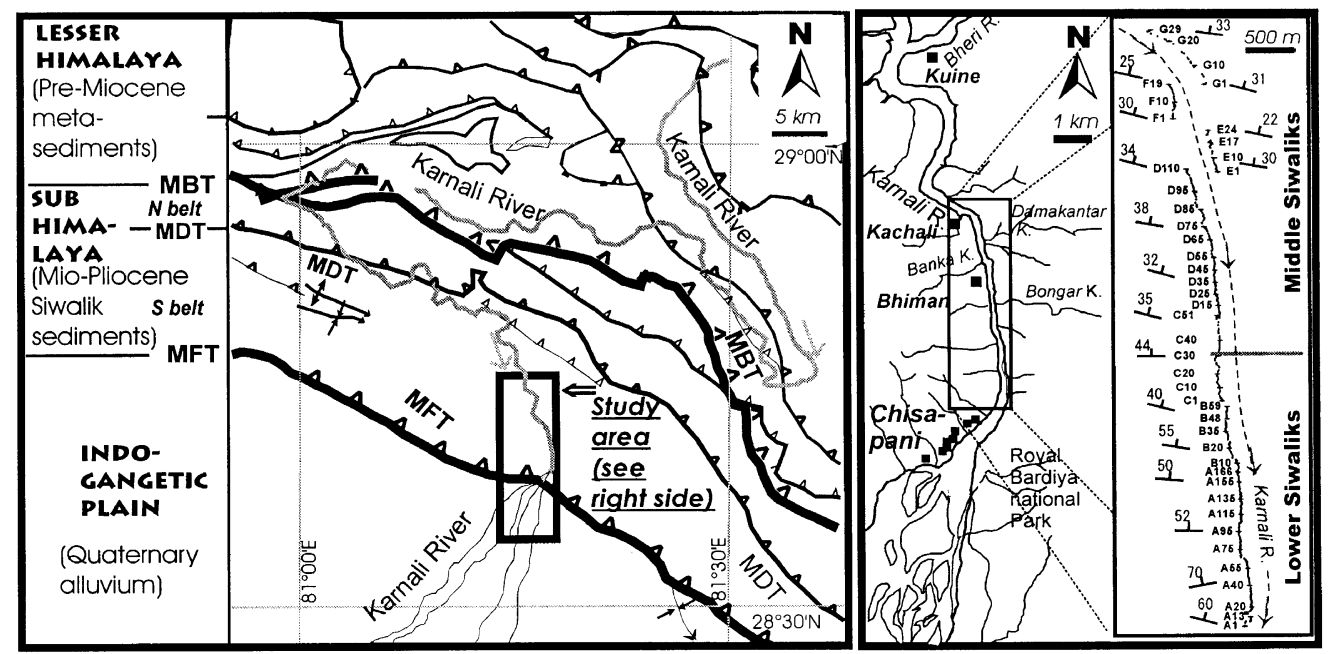

Fig. 1. Location, structural scheme and details of sampling of the Karnali river (KR) section. (a) Schematic map of the Himalayas showing the main geostructural units (after Gansser, 1964). The KR section is in western Nepal is indicated by a star. (b) Structural details around the KR section (modified after Mugnier et al., 1998). Major thrusts are: MFT = Main Frontal Thrust; MDT: Main Dun Thrust; MBT: Main Boundary Thrust. (c) Locations of sampling sites/levels. Segments A, B, C, D and F are situated at the right bank, whereas sites E and G are located in the left bank of the Karnali river. Only selected sites are shown for clarity.

The LS-MS boundary is placed at $2015 \mathrm{~m}$ level of the measured section where the first prominent bed ( $>5 \mathrm{~m}$ thick) of medium-to-coarse grained "salt and pepper" sandstone appears.

The LS sequence has a rhythmic alternation of mainly finegrained quartzose, partly calcareous, sandstones and commonly variegated mudstones. The sandstones are gray in the basal $(0-50 \mathrm{~m})$ and upper $(1180-2015 \mathrm{~m})$ parts. In the middle part (50-1180 m), they are commonly mottled giving reddish color. Many mudstone layers represent oxidized calcitic paleosols. The thickness of individual sandstone or mudstone bed varies between 0.5 to $5 \mathrm{~m}$. However, sandstone beds of 5-12 m, and very rarely of up to $20 \mathrm{~m}$, are also present and their frequency increases stratigraphically upwards. The LS facies represent deposits of a fine-grained meandering river system (Dhital et al., 1995).

The MS lithologies are represented by alternation of sand- stone and mudstone where the former predominates. The sandstones are generally medium to coarse-grained, gray, and mica-rich with "salt and pepper" appearance. The mudstone layers may in part represent drab-colored paleosols/histosols. The thickness of sandstone beds is typically several meters. But, it reaches $10-15 \mathrm{~m}$ at more than a dozen of levels while even more thicker $(15-50 \mathrm{~m})$ beds occur at several levels. Sandstones commonly exhibit trough and planar cross laminations as well as channel and scouring structures (up to 300 $\mathrm{cm}$ deep) with rip-up clasts. Pebble conglomerates intercalated with sandstones appear above $3175 \mathrm{~m}$ following a 50 $\mathrm{m}$ thick sandstone bed. A granule-bearing bed around 2725 $\mathrm{m}$ level contains vertebrate bone fragments (including teeth). The MS facies may be attributed mainly to a sandy braided river system (Ulak and Nakayama, 1998).

Generally, one or two cores $(2.54 \mathrm{~cm}$ in diameter and 6 to $12 \mathrm{~cm}$ in length) were obtained from 476 sandstone/siltstone 


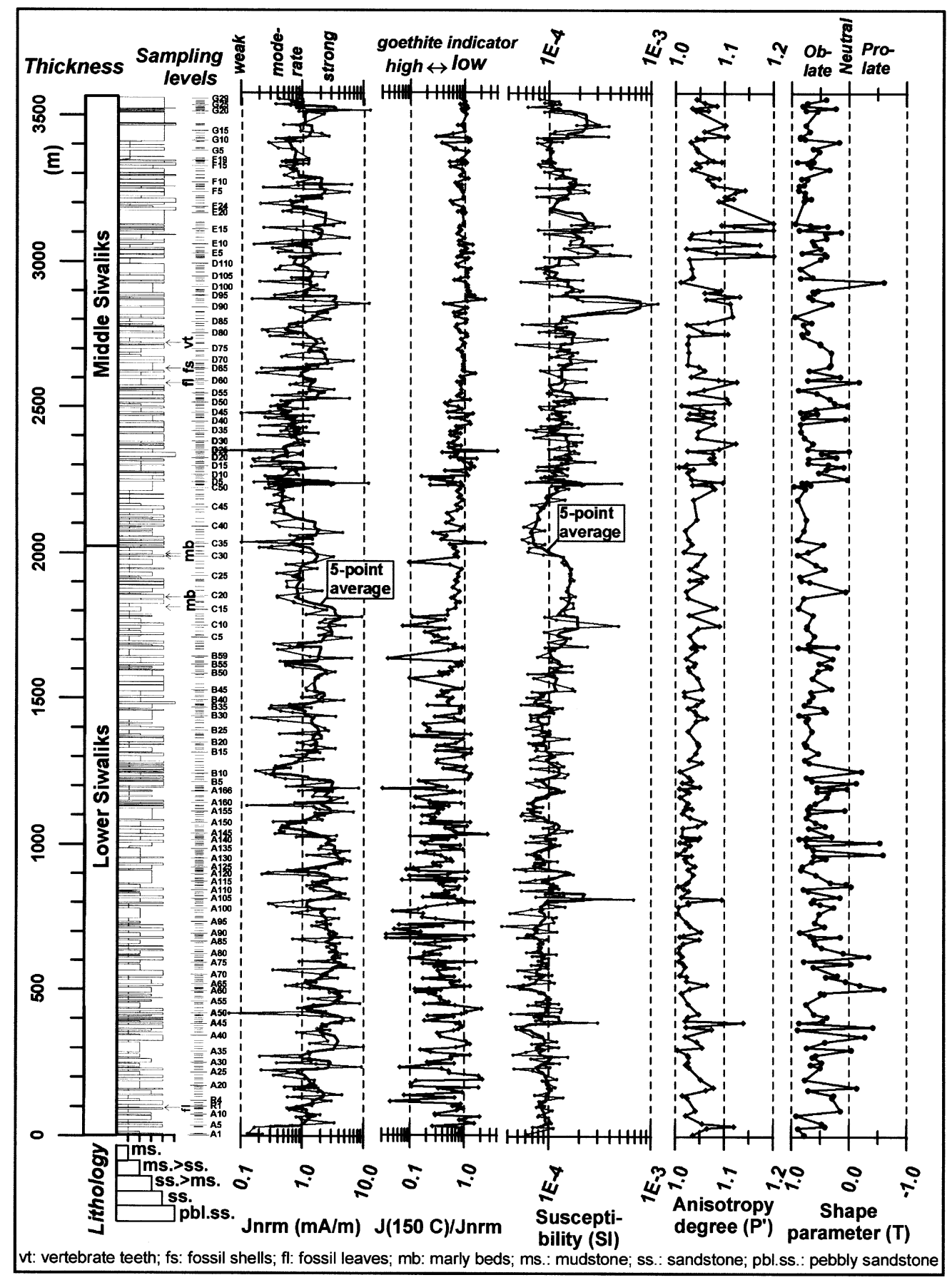

Fig. 2. Sampling positions plotted against the stratigraphic height (thickness) and the variations of selected rock magnetic and AMS parameters along the Karnali river section. In the log of lithology, the relative lengths of the horizontal bars correspond to varying grain size as shown at the base. For clarity, mudstone (ms.: clay and siltstone) and sandstone (ss.) layers are individualized only if the thickness is at least $4 \mathrm{~m}$; otherwise, they are shown as alternations (mudstone-dominated: ms.>ss.; or sandstone-dominated: ss.>ms.). $J_{\text {nrm }}$ and $J\left(150^{\circ} \mathrm{C}\right)$ denote the intensity of initial NRM and the residual remanence at $150^{\circ} \mathrm{C}$, respectively. $P^{\prime}$ and $T$ are the AMS parameters.

sites using a portable gasoline-powered drill and oriented with a magnetic compass. The seven segments, shown in Fig. 1(c), are tied to each other by tracing the beds laterally. The average site spacing is about $8 \mathrm{~m}$ in thickness and it never exceeds $40 \mathrm{~m}$. The measured section is regarded to be continuous as no significant fault or depositional hiatus has been recorded. The strata dip northward at varying angles, which gradually become gentler from the south $\left(\sim 60^{\circ}\right)$ to the north $\left(\sim 20^{\circ}\right)$.

\section{Laboratory Procedures}

The cores were cut to several standard specimens (about $2.3 \mathrm{~cm}$ in length). Magnetic measurements done at the laboratories of the University of Tubingen and Hokkaido University were conducted as follows:

(i) Analysis of natural remanent magnetization (NRM)

The NRMs of specimens were measured with a $2 \mathrm{G}$ Enterprises 755R SQUID magnetometer. Then, stepwise alternating field demagnetization (AFD) of the NRM was carried out 


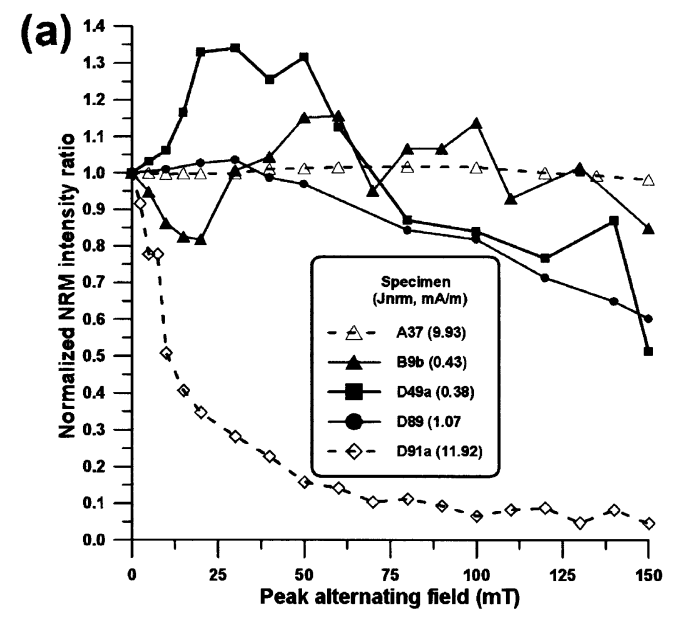

(b)
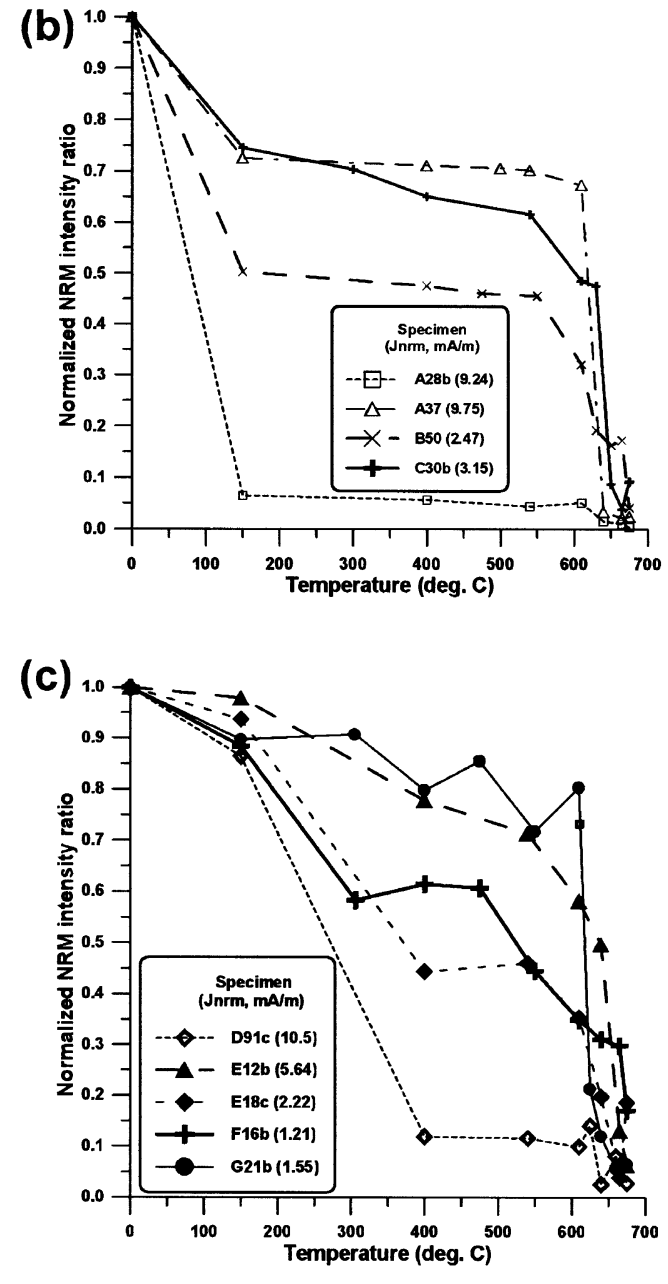

Fig. 3. Normalized magnetization intensity curves showing the response of representative specimens during demagnetization of NRM. (a) Alternating field demagnetization (AFD) curves. Most specimens show irregular response and insignificant $(<50 \%)$ reduction of the initial NRM suggesting general ineffectiveness of AFD up to $150 \mathrm{mT}$ (e.g. specimens A37, B9b, D49a, D89). Very few "salt and pepper" sandstone specimens exhibit the presence of soft-coercivity remanence as shown by the specimen D91a. (b) Thermal demagnetization (THD) curves for specimens (from LS lithologies) showing the predominance of two distinct unblocking temperature $\left(T_{u b}\right)$ ranges (low: $<150^{\circ} \mathrm{C}$ and high: $>600^{\circ} \mathrm{C}$ ). For specimen $\mathrm{A} 37$, normalization is done with respect to the residual remanence at $150 \mathrm{mT}$ (see the curve above). c) THD curves for specimens (from MS lithologies) showing the presence of two intermediate $T_{u b}$ ranges $\left(150-400^{\circ} \mathrm{C}\right.$ and $\left.400-600^{\circ} \mathrm{C}\right)$ in addition to the low and/or high ranges. up to field of $150 \mathrm{mT}$ on selected specimens with a static triaxial demagnetizer linked with the rock magnetometer. For comparison, stepwise thermal demagnetization (THD) up to $675^{\circ} \mathrm{C}$ was also applied on another set of specimens with a Magnetic Measurements MMTD60 furnace.

(ii) Isothermal remanent magnetization (IRM) experiments Twenty standard core specimens, which were selected on the basis of color, grain-size, lithology and stratigraphic positions representative of the whole section, were subjected to IRM acquisition in fields of up to $2.5 \mathrm{~T}$ with a Magnetic Measurements pulse magnetizer. The acquired IRM was measured with a Molspin spinner magnetometer. A laboratory-built 8-specimen capacity furnace was used for stepwise THD of the IRM. The remanence after each THD step was measured with a Schonstedt SSM-1A spinner magnetometer with a practical noise level of $\sim 0.1 \mathrm{~mA} \mathrm{~m}^{-1}$.

(iii) Studies on the magnetic susceptibility

Measurements of the low-field magnetic susceptibility $(\kappa)$ and anisotropic magnetic susceptibility (AMS: maximum $=$ $\kappa_{\text {max }}$, intermediate $=\kappa_{\text {int }}$, minimum $\left.=\kappa_{\text {min }}\right)$ of standard specimens were conducted with an AGICO KLY-3S Kappabridge system. To investigate the variations in $\kappa$ during heating, small subsamples $\left(\sim 0.5 \mathrm{~cm}^{3}\right)$ were monitored by the heatingcooling cycle in air with the system and an attached CS-3 furnace.

\section{Rock Magnetic Properties 4.1 NRM and demagnetization}

The NRM intensity of specimens lies mostly within $10^{-1}$ and $10 \mathrm{~mA} \mathrm{~m}^{-1}$ (Fig. 2). Stepwise AFD of selected specimens up to $150 \mathrm{mT}$ reveals that the NRM intensity of the majority of red siltstones is virtually unaffected by the applied fields (Fig. 3(a), specimens A37 and B9b), indicating a very high coercivity spectrum of the NRM. For most gray sandstones, the applied maximum field is inadequate to reduce the initial intensity to half its value (Fig. 3(a), specimens D49a and D89). However, a minor fraction of remanence in such specimens is clearly magnetically soft (cleaned below 25-30 mT fields). An exceptionally high contribution of the soft fraction is exhibited by very few specimens represented by medium-grained sandstones (e.g. specimen D91a, Fig. 3(a)). The magnetic minerals that carry remanences with such different coercivities are discussed below.

On the basis of prevailing unblocking temperature $\left(T_{u b}\right)$ ranges seen in the THD data, the investigated specimens can be classified into two groups. Figure 3(b) shows the behavior of the first group, which includes most specimens from LS lithologies, characterized by the predominance of two distinct $T_{u b}$ ranges: $<150^{\circ} \mathrm{C}$ (low $T_{u b}$ ) and $>600^{\circ} \mathrm{C}$ (high $T_{u b}$ ). Specimen A37, which completely resisted AFD up to 150 $\mathrm{mT}$ as seen in Fig. 3(a), belongs to this group (Fig. 3(b)). The second group is represented by sandstone specimens, commonly from MS lithologies, which exhibit the presence of intermediate $T_{u b}$ range (lower: $150-400^{\circ} \mathrm{C}$ and/or upper: $400-600^{\circ} \mathrm{C}$ ) in addition to the varying contribution from low and high $T_{u b}$ ranges (Fig. 3(c)). Comparison of the responses of two sister specimens, subjected to different types of demagnetization (D91a-AF; and D91c-thermal), suggests that the soft magnetic fraction is likely to correspond to the lower intermediate $\left(150-400^{\circ} \mathrm{C}\right) T_{u b}$ range. 


\subsection{IRM acquisition and thermal demagnetization}

IRM acquisition and its THD curves are grouped on the basis of the coercivities (see, for example, Dunlop and Özdemir, 1997: section 15.3.4) and unblocking temperature ranges (Fig. 4). The characteristics of the specimens in the respective groups are as follows:

a) No saturation of acquired IRM within the applied fields (Fig. 4(a)). The specimens show significant $(>50 \%)$ reduction of the acquired IRM intensity in two distinct temperature ranges $\left(<100-150^{\circ} \mathrm{C}: 25-80 \%\right.$ and $\left.>600^{\circ} \mathrm{C}: 5-35 \%\right)$. Such demagnetization behavior is identical to that shown by specimens included into the 'first group' according to the thermal demagnetization of NRM.

b) Almost complete saturation of acquired IRM at low to intermediate fields and decay of a large part of the initial IRM between $100-400^{\circ} \mathrm{C}$ (Fig. 4(b)). The specimens acquire $>80 \%$ of IRM between 100 and $500 \mathrm{mT}$. The $T_{u b}$ range of significant unblocking is identical to the 'lower intermediate $T_{u b}$ range' seen in NRM demagnetization curves. A small part of the IRM is seen to persist to high $T_{u b}$ range $\left(>600^{\circ} \mathrm{C}\right)$. c) Almost complete saturation of acquired IRM at intermediate to high fields and lack of distinct low or intermediate $T_{u b}$ ranges (Fig. 4(c)). About $70 \%$ of the total IRM decays almost linearly with temperature between 100 and $600^{\circ} \mathrm{C}$.

\subsection{Magnetic minerals as the carriers of remanence}

The dominantly linear nature of the IRM acquisition curves at relatively high fields resulting in lack of saturation even at $2.5 \mathrm{~T}$ and the low $T_{u b}\left(<150^{\circ} \mathrm{C}\right)$ range seen in both the NRM and IRM demagnetization curves are interpreted to reflect the presence of goethite $(\alpha-\mathrm{FeOOH})$. The high $T_{u b}\left(>600^{\circ} \mathrm{C}\right)$ points to the presence of hematite $\left(\alpha-\mathrm{Fe}_{2} \mathrm{O}^{3}\right)$. Marked loss of NRM or IRM intensity within the $150-400^{\circ} \mathrm{C}$, the soft coercivity shown by almost complete saturation of the IRM at relatively low fields and the magnetically soft fraction of NRM seen in AFD curves are indicative of maghemite $(\gamma$ $\mathrm{Fe}_{2} \mathrm{O}^{3}$ ). In addition, unblocking of a fraction of NRM or IRM between $400-600^{\circ} \mathrm{C}$ range and moderate hardness of NRM to AFD (e.g. specimen D91a in Fig. 3(a)) suggest occasional presence of magnetite $\left(\mathrm{Fe}_{3} \mathrm{O}^{4}\right)$ as well. Based on such interpretation, the three groups of curves in Fig. 4 reflect the remanence contribution predominated by the following magnetic minerals: a) goethite and hematite; b) maghemite and hematite; and (c) maghemite and/or magnetite and hematite.

As goethite has a Néel temperature of about $120^{\circ} \mathrm{C}$, the remanence residing in it is completely demagnetized at the $150^{\circ} \mathrm{C}$ step. Hence, the ratio $J\left(150^{\circ} \mathrm{C}\right) / J_{\mathrm{NRM}}$ may be used as a 'goethite indicator'. A vertical log of this ratio is shown in Fig. 2. The contribution of goethite to the remanence is significant below $1800 \mathrm{~m}$ of the KR section, especially in the colored muddy sandstones and siltstones (LS lithologies), but persists to the level of $2500 \mathrm{~m}$. Judging from the THD data, maghemite's contribution to NRM is significant above $1600 \mathrm{~m}$, especially in "salt and pepper" sandstones (MS lithologies). Hematite contributes to the remanence in all specimens throughout the section.

Detailed analysis of the magnetic remanence, in connection with magnetostratigraphic dating of the KR section, revealed two components: a normal polarity component of recent field (RF) origin and a dual-polarity characteristic remanence (ChRM) (Gautam and Fujiwara, 1999). In general, the
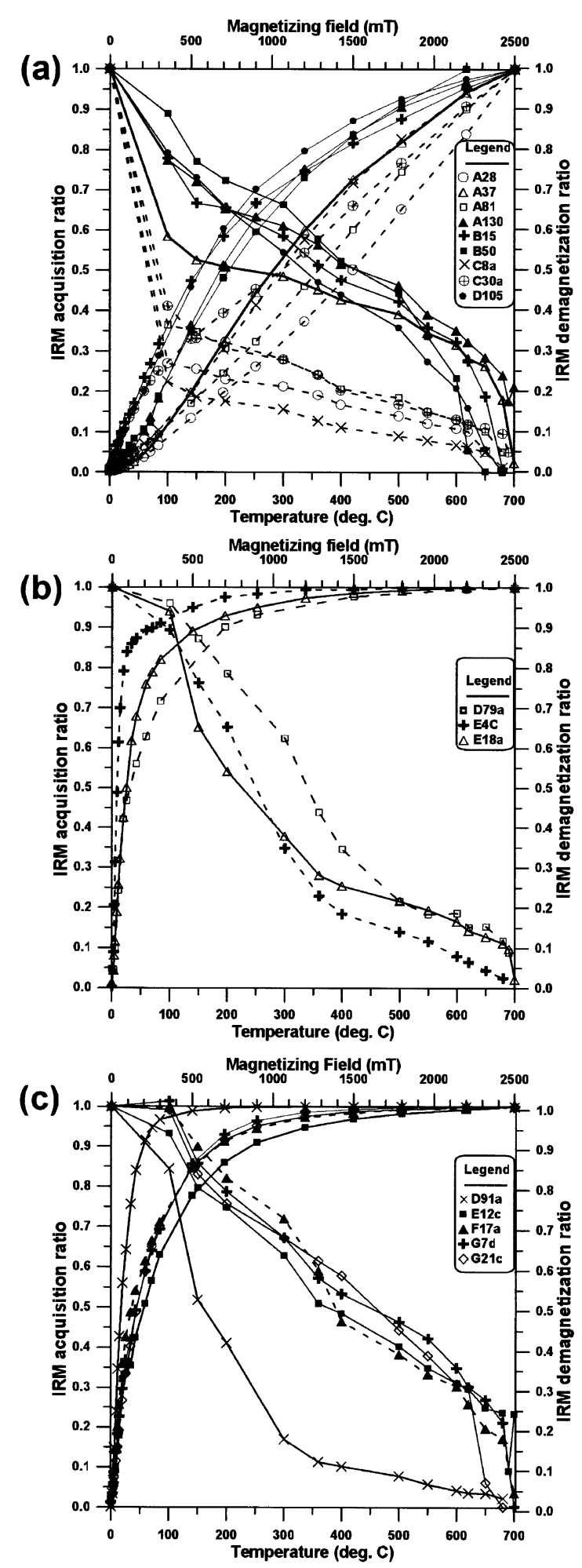

Fig. 4. Curves showing acquisition (ascending) and thermal demagnetization (descending) of IRM for representative specimens. According to the IRM saturation characteristics and unblocking temperatures, the diagrams are interpreted to reflect the predominance by certain kinds of magnetic minerals: (a) goethite and hematite; (b) maghemite and hematite; and c) maghemite and/or magnetite and hematite.

$\mathrm{RF}$ component resides in goethite in varicolored muddy specimens (LS lithologies), but in maghemite in the gray faciesespecially the "salt and pepper" sandstones (MS lithologies). As goethite and maghemite carry the RF component, their 


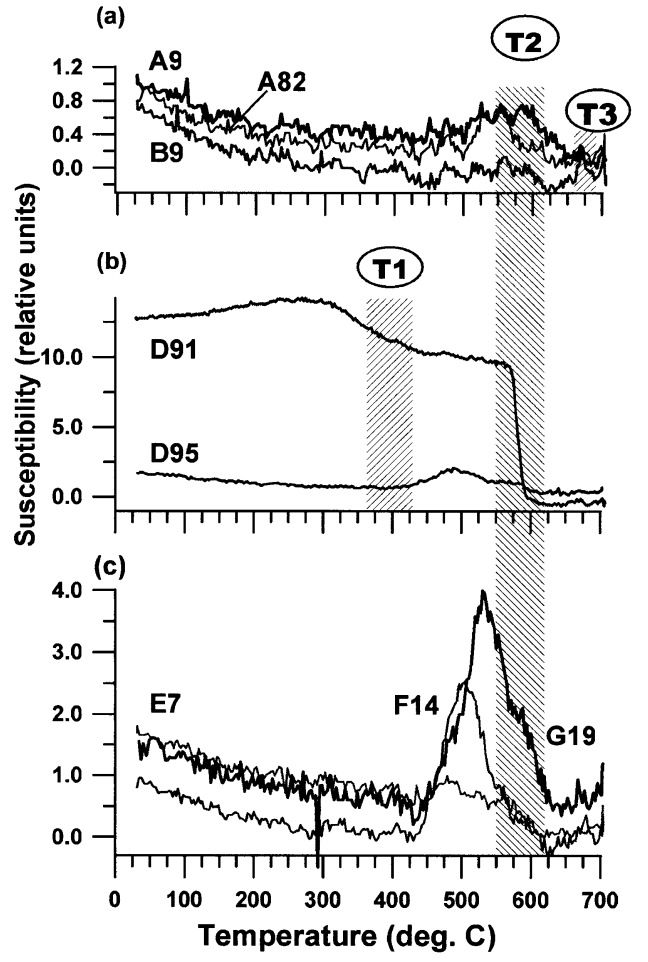

Fig. 5. Magnetic susceptibility vs. temperature curves for chip/powdered specimens during heating. Specimens A9, A82 and B9 are red-colored siltstones but the rest are gray sandstones. In several curves, the initial part $\left(<200-300^{\circ} \mathrm{C}\right)$ follows a hyperbolic course indicating the paramagnetic effect. Temperature ranges shown by shades correspond to maghemite decomposition $\left(T_{1}\right)$, Curie temperatures of magnetite or oxidized magnetite-like phase $\left(\mathrm{T}_{2}\right)$, and decay of the hematite-based susceptibility $\left(\mathrm{T}_{3}\right)$. Production of new magnetic minerals during heating starts already at $425^{\circ} \mathrm{C}$ leading to increase in susceptibility.

formation may owe to the weathering-related processes in present day environment (Taylor and Schwertmann, 1974; Schwertmann, 1988). The ChRM resides in hematite and it has well-defined dual polarity nature. The average inclination after bedding correction is about $20^{\circ}$ (positive: normal; negative: reverse), which is $\sim 50 \%$ shallower than the expected inclination. This fact is taken as an evidence for the primary detrital remanent magnetization (DRM) (Tauxe and Kent, 1984; Gautam and Appel, 1994). A tentative polarity sequence based on this ChRM and its correlation with the GPTS (Cande and Kent, 1995) suggests an age of 16-5 Ma for the $3560 \mathrm{~m}$ section (Gautam and Fujiwara, 1999).

\subsection{Low-field magnetic susceptibility $(\kappa)$ and its varia-} tion with temperature

The magnitudes of $\kappa$ for the KR section vary between 3 $\times 10^{-5}$ and $10^{-3}$ SI (Fig. 2). Low $\kappa$ values indicate that the contribution of paramagnetic particles is dominant. On the other hand, the "salt and pepper" sandstones (MS lithologies) show high values $\left(\kappa>10^{-4} \mathrm{SI}\right)$ because of the contribution from the ferromagnetic phases such as maghemite/magnetite. The logs in Fig. 2 do not show straightforward correlation between the NRM intensities and magnitudes of susceptibility.

From the 5-point averaged values, three segments with distinct susceptibility variation patterns may be noted. Within the lower segment ( 0 to $1600 \mathrm{~m}$ ), $\kappa$ shows frequent variations with an average remaining mostly below $10^{-4} \mathrm{SI}$. In the middle segment $(1600-2200 \mathrm{~m}), \kappa$ varies smoothly within $\sim 600$ $\mathrm{m}$ of the section where the average value fluctuates between $5 \times 10^{-5}$ and $2 \times 10^{-4}$ SI. Within the upper segment $(2200$ $3560 \mathrm{~m}$ ), the average $\kappa$ commonly exceeds $10^{-4} \mathrm{SI}$ and again exhibits frequent variations.

Figure 5 shows the magnetic susceptibility vs. temperature curves. A gently sloping segment in the initial part, between 30 and $200-300^{\circ} \mathrm{C}$, of the curves of many specimens (e.g. A9, A82, B9, D95, E7, F14 and G19) corresponds to the hyperbolic offset arising from the paramagnetic minerals (Hrouda, 1994). That the hyperbola almost completely fits the initial part of many curves points to the predominance of paramagnetic contribution. A few specimens clearly indicate the presence of ferromagnetic minerals in unheated specimens. The specimen D91 contains maghemite as indicated by the loss of susceptibility between 300 and $400^{\circ} \mathrm{C}$ during heating. It contains also magnetite as evidenced by the sharp susceptibility drop around $580^{\circ} \mathrm{C}$ - the Curie temperature of Ti-poor or pure magnetite (Fig. 5(b)). The heating curve for specimen A9 shows a susceptibility tail, above $600^{\circ} \mathrm{C}$, which gradually decreases and vanishes around $675-680^{\circ} \mathrm{C}$ (Fig. 5(a)). These observations suggest the presence of hematite (Néel temperature of $\sim 680^{\circ} \mathrm{C}$ ).

\section{Magnetic Fabric}

The preferred orientation of grains and/or crystal lattice of all types of magnetic minerals constituting a rock contributes to the magnetic fabric (see Hrouda, 1982). The AMS method is effective in characterizing such fabric recorded by the sediments of the Siwalik Group (Tauxe et al., 1990; Gautam and Rösler, 1999). It involved determination of the principal susceptibility directions $\left(\kappa_{\max } \geq \kappa_{\text {int }} \geq \kappa_{\min }\right)$ as well as the quality and quantity of the fabric by calculating the shape factor $(T)$ and the corrected degree of anisotropy $\left(P^{\prime}\right)$, respectively, following Jelinek (1981):

$$
\begin{aligned}
& T=\left(2 \eta_{\text {int }}-\eta_{\max }-\eta_{\min }\right) /\left(\eta_{\max }-\eta_{\min }\right) \\
& P^{\prime}=\exp \sqrt{2\left[\left(\eta_{\max }-\eta_{m}\right)^{2}+\left(\eta_{\text {int }}-\eta_{m}\right)^{2}+\left(\eta_{\min }-\eta_{m}\right)^{2}\right]}
\end{aligned}
$$

where, $\eta_{\max }=\ln \kappa_{\max } ; \eta_{\text {int }}=\ln \kappa_{\text {int }} ; \eta_{\min }=\ln \kappa_{\min } ; \eta_{m}=$ $\ln \kappa_{m}$, and $\kappa_{m}=\left(\kappa_{\max }+\kappa_{\text {int }}+\kappa_{\min }\right) / 3$ is the mean susceptibility.

On the scale of a site or section, clustered $\kappa_{\min }$ axes correspond to the pole of the "magnetic foliation plane" whereas clustering of the $\kappa_{\max }$ axes defines the "magnetic lineation". The condition $0<T \leq 1$ determines a planar fabric whereas $-1 \leq T<0$ is valid for a linear one.

\subsection{AMS magnitudes for Siwaliks sediments of the KR section}

The $P^{\prime}$ and $T$ values for about half of the sampled sites (1 specimen from each) are shown in Fig. 2 (right side) against the lithological column. With the exception of a few extremely high values correlatable to high susceptibility values, $P^{\prime}$ is less than 1.20. There is no correlation between the values of either $P^{\prime}$ or $T$ with stratigraphic height or age. Figure 6 clearly shows that the anisotropy ellipsoids are mostly oblate $(T>0)$. The wide range of $P^{\prime}$ found to be maximum for highly oblate specimens narrows down with changes in 


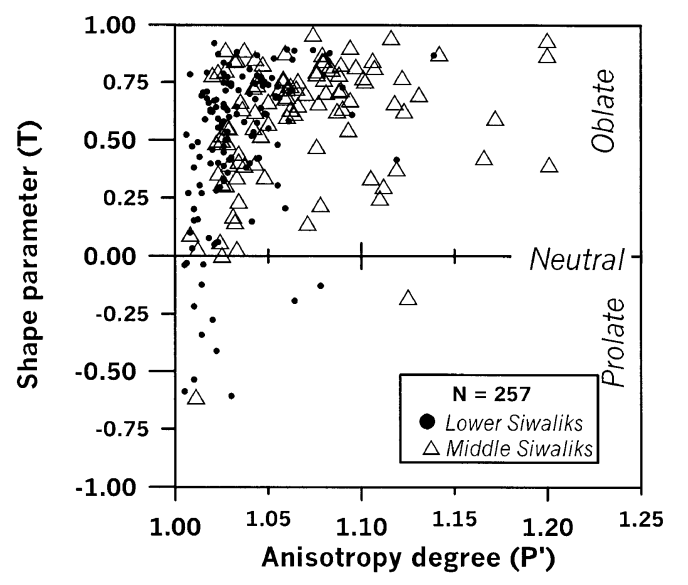

Fig. 6. Relationship between the susceptibility ellipsoid shape $(T)$ and the degree of anisotropy $\left(P^{\prime}\right)$. Note the dominantly oblate nature of the magnetic fabric.

shape towards prolate field.

\subsection{Principal AMS directions}

The in situ $\kappa_{\min }$ axes form clusters similar to those defined by the poles to the bedding measured at the sampling sites (Fig. 7; contouring done after Robin and Jowett, 1986). The other two axes ( $\kappa_{\max }$ and $\kappa_{\text {int }}$; in situ) define girdle-like distribution approximating planes (magnetic foliation) subparallel to the bedding indicating that the "magnetic foliation" was formed before the tilting of the strata. Analysis of the tilt-corrected $\kappa_{\max }$ directions within individual sampling segments (A-G: see Fig. 1(c)) suggests that they yield similar sub-horizontal average trends with some scattering which is independent of the lithology, age or stratigraphic position. The magnetic lineations point mainly towards $75^{\circ}-130^{\circ}$ or $245^{\circ}-310^{\circ}$ and yield a peak orientation of $290^{\circ} / 2.8^{\circ}$ (Fig. 8).

5.3 Origin of the magnetic fabric: sedimentary and tectonic implications

Interpretation of the observed magnetic fabric requires consideration of the relevant data on paleocurrent directions, bedding attitudes and tectonism. Unfortunately, the KR section has not been studied for paleocurrents so far and the only way to infer the probable paleocurrent direction is through interpolation from the adjacent sections. Limbs of trough cross-strata occurring within the LS and MS facies of a $\sim 3.4$ $\mathrm{km}$ thick section at Khutia Khola, which is situated at $\sim 50$ $\mathrm{km}$ to the west of the present section, yield average trough axes azimuths within $120^{\circ}-200^{\circ}$ range (the overall mean has an azimuth of $160^{\circ}$ ) suggestive of consistently southward paleocurrent directions (Decelles et al., 1998). The paleocurrent directions derived from the sandstones constituting the LS and MS facies of the Surai Khola section, situated at $\sim 150-170 \mathrm{~km}$ to the east of the KR section, are found to be southeastward by Burbank et al. (1996) but southwestward by Decelles et al. (1998). Based on these data, the most likely paleoflows in the KR section are inferred to be roughly southward.

The observed strikes of the bedding planes along the Karnali river section lie mostly between E-W and NW-SE. The thrust fronts in the vicinity of the KR section show commonly WNW-ESE trends (Fig. 1(b)). Therefore, the observed mag-

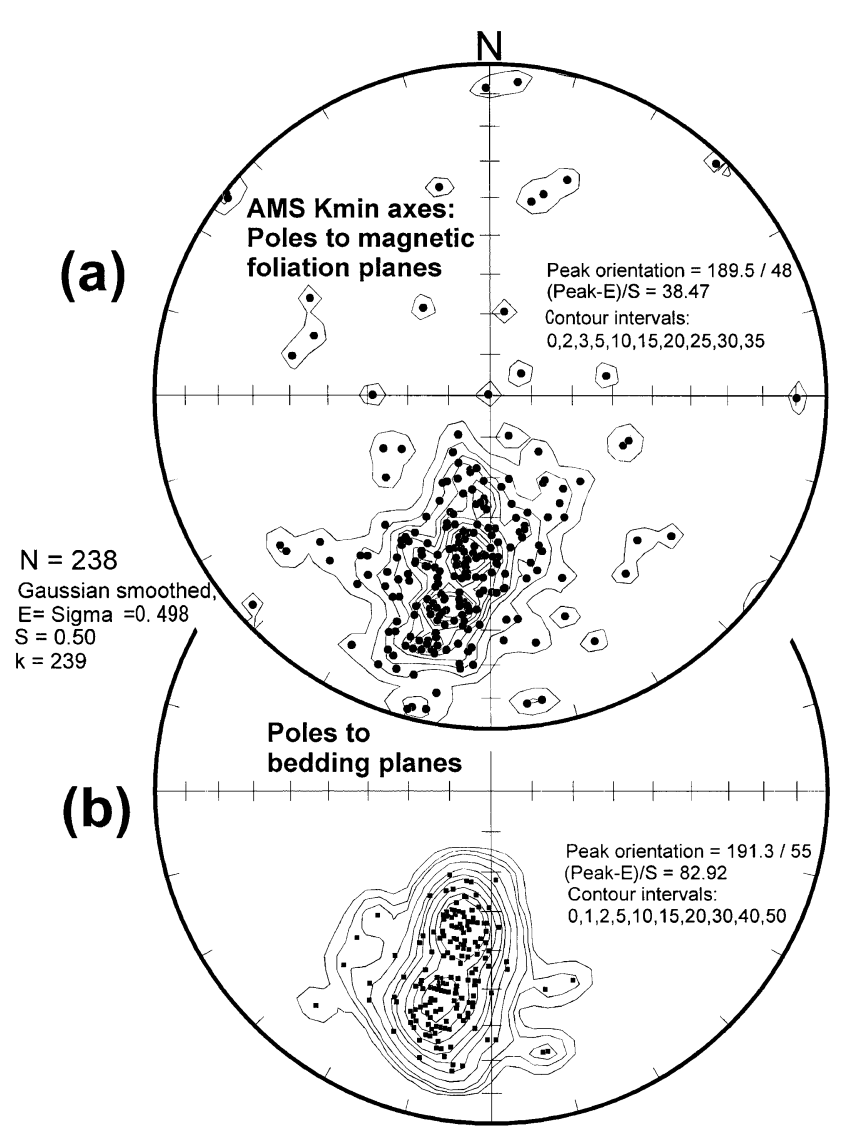

Fig. 7. Comparison between the in situ AMS minimum axes (magnetic foliation poles) (a) derived from standard cylindrical specimens $\left(11 \mathrm{~cm}^{3}\right)$ representing 238 sampling levels and the poles to the bedding planes (b) measured at each level at the outcrop. The subparallelism between these two directions and similarity of the average or peak directions may be noted.

\section{AMS Kmax axes: magnetic lineations}

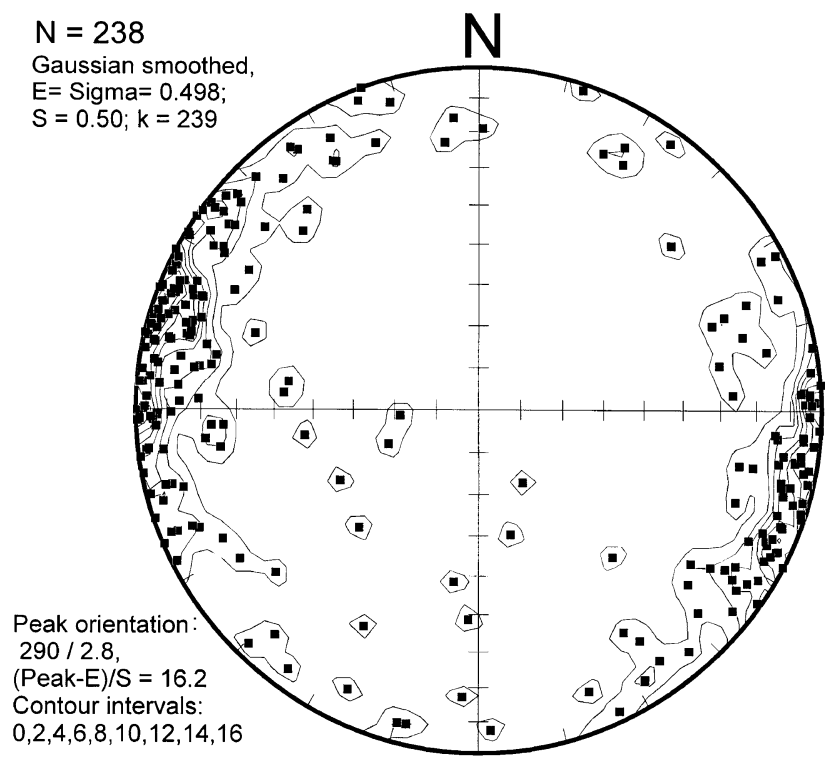

Fig. 8. Plot of the tilt-corrected AMS maximum axes (magnetic lineations) derived from standard specimens mentioned in Fig. 7. Note the sub-horizontal nature of these axes and the well-defined clusters along WNW-ESE direction. 
netic lineations are subparallel to the fold axes/bedding strikes/thrust fronts rather than to the expected paleocurrent direction.

The magnetic fabric observed in the KR section has characteristics which are similar to those found for other Siwalik sections in central Nepal (Gautam and Rösler, 1999). It is interpreted to result from the combination of an initial sedimentary-compactional fabric and a later secondary tectonic fabric induced by a mild deformation process. Such a fabric is similar to that found in apparently undeformed or weakly deformed Tertiary sediments of the orogenic belts in the northwestern Greece, Taiwan, the west Carpathians, the western Taurus of Turkey and the northern Apennines of Italy with compressive tectonic setting (Kissel et al., 1986; Lee et al., 1990; Hrouda and Potfaj, 1993; Aubourg et al., 1997; Sagnotti et al., 1998).

\section{Conclusions}

(1) Goethite, maghemite/magnetite and hematite carry the magnetic remanence in the Siwalik Group sediments studied. Goethite-based remanence contributes up to $90 \%$ of NRM in muddy lithologies from the Lower Siwaliks. In contrast, there is almost no goethite in the sandstones from the Middle Siwaliks but the maghemite/magnetite contribution to the total NRM in them reaches up to $50 \%$. The ChRM believed to be a DRM or post-depositional DRM residing in hematite is preserved in all specimens but its recovery may require thermal treatment well above the Curie temperature of magnetite (say above $600^{\circ} \mathrm{C}$ ) to demagnetize the secondary components residing in goethite, maghemite and magnetite.

(2) Magnetic foliation derived from the AMS is mostly parallel to the bedding plane indicating its origin prior to the tilting of the strata. The mean magnetic lineation, however, has a trend of $290^{\circ} / 2.8^{\circ}$, which is subparallel to the thrust fronts/fold axes in the area and thus is believed to result from the mild tectonic deformation active during the ongoing sedimentation process as well as later. The anisotropy degree $\left(P^{\prime}\right)$ is mostly below 1.20 being typical for the fluvial sediments.

Acknowledgments. We are grateful to E. Appel for arranging a short visit of one of us (PG) to Tubingen for cooperative research on 'paleomagnetic rotations in the Himalayas' under a program sponsored by the German Research Council (DFG). We are much indebted to J.-L. Mugnier and H. Pascale of the University of Grenoble for introducing us to the Karnali section. Comments and suggestions by F. Hrouda and an anonymous reviewer helped to improve the manuscript. We thank Nina G. Jablonski of California Academy of Sciences for kindly reading and correcting the English of the manuscript. The long-term invitational fellowship from the Japan Society for the Promotion of Science (JSPS) to PG is gratefully acknowledged.

\section{References}

Appel, E., W. Rösler, and G. Corvinus, Magnetostratigraphy of the MiocenePleistocene Surai Khola Siwaliks in west Nepal, Geophys. J. Int., 105, 191-198, 1991.

Aubourg, C., D. Frizon de Lamotte, A. Poisson, and E. Mercier, Magnetic fabrics and oblique ramp-related folding: a case study from the western Taurus (Turkey), J. Struct. Geol., 19, 1111-1120, 1997.

Barndt, J., N. M. Johnson, G. D. Johnson, N. D. Opdyke, E. H. Lindsay, D. Pilbeam, and R. A. K. Tahirkheli, The magnetic polarity stratigraphy and age of the Siwalik Group near Dhok Pathan village, Potwar Plateau, Pakistan, Earth Planet. Sci. Lett., 41, 355-364, 1978.
Burbank, D. W., R. A. Beck, and T. Mulder, The Himalayan foreland basin, in The Tectonic Evolution of Asia, edited by A. Yin and M. Harrison, pp. 149-188, Cambridge University Press, 1996.

Cande, S. C. and D. V. Kent, Revised calibration of the geomagnetic polarity timescale for the Late Cretaceous and Cenozoic, J. Geophys. Res., 100, 6093-6095, 1995

Decelles, P. G., G. E. Gehrels, J. Quade, T. P. Ojha, P. A. Kapp, and B. N. Upreti, Neogene foreland basin deposits, erosional unroofing, and the kinematic history of the Himalayan fold-thrust belt, western Nepal, GSA Bulletin, 110, 2-21, 1998.

Dhital, M. R., A. P. Gajurel, D. Pathak, L. P. Paudel, and K. Kizaki, Geology and structure of the Siwaliks and Lesser Himalaya in the Surai KholaBardanda area, mid Western Nepal, Bull. Dept. Geol., Tribhuvan Univ., 4, special issue, 1-70, 1995.

Dunlop, D. J. and Ö. Özdemir, Rock Magnetism: Fundamentals and Frontiers, 573 pp., Cambridge University Press, 1997.

Gansser, A., Geology of the Himalayas, 264 pp., Wiley Interscience, London, 1964.

Gautam, P. and E. Appel, Magnetic-polarity stratigraphy of Siwalik Group sediments of Tinau Khola section in west central Nepal, revisited, Geophys. J. Int., 117, 223-234, 1994.

Gautam, P. and S. R. Pant, Magnetic fabric of Siwalik Group sediments of Tinau Khola section, west central Nepal, Bull. Dept. Geol., Tribhuvan Univ., 5, 21-36, 1996

Gautam, P. and W. Rösler, Depositional chronology and fabric of Siwalik Group sediments in central Nepal from magnetostratigraphy and magnetic anisotropy, in Geology of the Nepal Himalaya: Recent Advances, edited by P. LeFort and B. N. Upreti, J. Asian Earth Sciences, 17, 659$682,1999$.

Gautam, P. and Y. Fujiwara, Magnetic polarity stratigraphy of Siwalik Group sediments from the Karnali river Section in western Nepal, in Terra Nostra 2 (Abstracts of the $14^{\text {th }}$ Himalaya-Karakoram-Tibet Workshop), pp. 5355, Kloster Ettal, Germany, 1999.

Harrison, T. M., P. Copeland, S. A. Hall, J. Quade, S. Burner, T. P. Ojha, and W. S. F. Kidd, Isotopic preservation of Himalayan/Tibetan uplift, denudation, and climatic histories in two molasse deposits, J. Geology, 101, 157-175, 1993.

Hrouda, F., Magnetic anisotropy of rocks and its application in geology and geophysics, Geophys. Surv., 5, 37-82, 1982.

Hrouda, F., A technique for the measurement of thermal changes of magnetic susceptibility of weakly magnetic rocks by the CS-2 apparatus and KLY-2 Kappabridge, Geophys. J. Int., 118, 604-612, 1994.

Hrouda, F. and M. Potfaj, Deformation of sediments in the post-orogenic Intra-Carpathian Paleogene Basin as indicated by magnetic anisotropy, Tectonophys., 224, 425-434, 1993.

Jelinek, V., Characterization of magnetic fabric of rocks, Tectonophys., 79, T63-T67, 1981

Johnson, N. M., N. D. Opdyke, G. D. Johnson, E. H. Lindsay, and R. A. K. Tahirkheli, Magnetic polarity stratigraphy and ages of Siwalik Group rocks of the Potwar Plateau, Pakistan, Paleogeogr. Paleoclimatol. Paleoecol., 37, 17-42, 1982.

Johnson, G. D., N. D. Opdyke, S. K. Tandon, and A. C. Nanda, The magnetic polarity stratigraphy of the Siwalik Group at Haritalyangar (India) and a new last appearance datum for Ramapithecus and Sivapithecus in Asia, Palaeogeogr. Palaeoclimatol. Palaeoecol., 44, 223-249, 1983.

Kissel, C., C. Laj, and A. Mazaud, First paleomagnetic results from Neogene formations in Evia, Skyros and the Volos region and the deformation of central Aegea, Geophys. Res. Lett., 13, 1446-1449, 1986.

Lee, T. Q., C. Kissel, C. Laj, C. S. Horng, and Y. T. Lue, Magnetic fabric analysis of the Plio-Pleistocene sedimentary formations of the Coastal Range of Taiwan, Earth Planet. Sci. Lett., 98, 23-32, 1990.

Mugnier, J. L., B. Delcaillau, P. Huyghe, and P. Leturmy, The break-back thrust splay of the Main Dun Thrust (Himalayas of western Nepal): evidence of an intermediate displacement scale between earthquake slip and finite geometry of thrust systems, J. Struct. Geol., 20, 857-864, 1998.

Opdyke, N. D., Magnetic stratigraphy of Cenozoic terrestrial sediments and mammalian dispersal, J. Geology, 98, 621-637, 1990.

Opdyke, N. D., E. Lindsay, G. D. Johnson, N. M. Johnson, R. A. K Tahirkheli, and M. A. Mirza, Magnetic polarity stratigraphy and vertebrate paleontology of the Upper Siwalik subgroups of Northern Pakistan, Paleogeogr. Paleoclimatol. Paleoecol., 27, 1-34, 1979.

Ranga Rao, A., R. P. Agarwal, U. N. Sharma, M. S. Bhalla, and A. C. Nanda, Magnetic polarity stratigraphy and vertebrate paleontology of the upper Siwalik subgroup of Jammu Hills, India, Geol. Soc. India Journal, 31, 361-385, 1988 . 
Robin, P.-Y. F. and E. C. Jowett, Computerized density contouring and statistical evaluation of orientation data using counting circles and continuous weighting functions, Tectonophys., 121, 207-223, 1986.

Rösler, W. and E. Appel, Fidelity and time resolution of the magnetostratigraphic record in Siwalik sediments: high-resolution study of a complete polarity transition and evidence for cryptochrons in Miocene fluviatile section, Geophys. J. Int., 135, 861-875, 1998.

Rösler, W., W. Metzler, and E. Appel, Neogene magnetic polarity stratigraphy of some fluviatile Siwalik sections, Nepal, Geophys. J. Int., 130, 89-111, 1997.

Sagnotti, L., F. Speranza, A. Winkler, M. Mattei, and R. Funiciello, Magnetic fabric of clay sediments from the external northern Apennines (Italy), Phys. Earth Planet. Int., 105, 73-93, 1998.

Schwertmann, U., Occurrence and formation of iron oxides in various pedoenvironments, in Iron in Soils and Clay Minerals, edited by J. W. Stucki et al., pp. 267-308, D. Reidel, Norwell, MA, 1988.

Tauxe, L. and D. V. Kent, Properties of a detrital remanence carried by haematite from study of modern river deposits and laboratory redeposition experiments, Geophys. J. R. Astron. Soc., 76, 543-561, 1984.

Tauxe, L. and N. D. Opdyke, A time framework based on magnetostratig- raphy for the Siwalik sediments of the Khaur area, northern Pakistan, Palaeogeogr., Palaeoclimatol., Palaeoecol., 37, 43-61, 1982.

Tauxe, L., C. Constable, L. Stokking, and C. Badgley, Use of anisotropy to determine the origin of characteristic remanence in the Siwalik red beds of Northern Pakistan, J. Geophys. Res., 95, 4391-4404, 1990.

Taylor, R. M. and U. Schwertmann, Maghemite in soils and its origin, I. Properties and observations on soil maghemites, Clay Mineral., 10, 299310, 1974.

Tokuoka, T., K. Takayasu, M. Yoshida, and K. Hisatomi, The Churia (Siwalik) Group of the Arung Khola area, west central Nepal, Mem. Fac. Sci., Shimane Univ., 20, 135-210, 1986.

Ulak, P. D. and K. Nakayama, Lithostratigraphy and evolution of fluvial style of the Siwalik Group in the Hetauda-Bakiya Khola area, central Nepal, Bull. Dept. Geol., Tribhuvan Univ., 6, 1-14, 1998.

P. Gautam (e-mail: pitambar.gautam@uni-tuebingen.de), A. Hosoi, K. R. Regmi, D. R. Khadka, and Y. Fujiwara (e-mail: fujiwara@ep.sci.hokudai. ac.jp) 